\title{
Complete Bouguer and Isostatic Residual Gravity Maps of the Anadarko Basin, Wichita Mountains, and Surrounding Areas, Oklahoma, Kansas, Texas, and Colorado
}

\section{U.S. GEOLOGICAL SURVEY BULLETIN 1866-G}

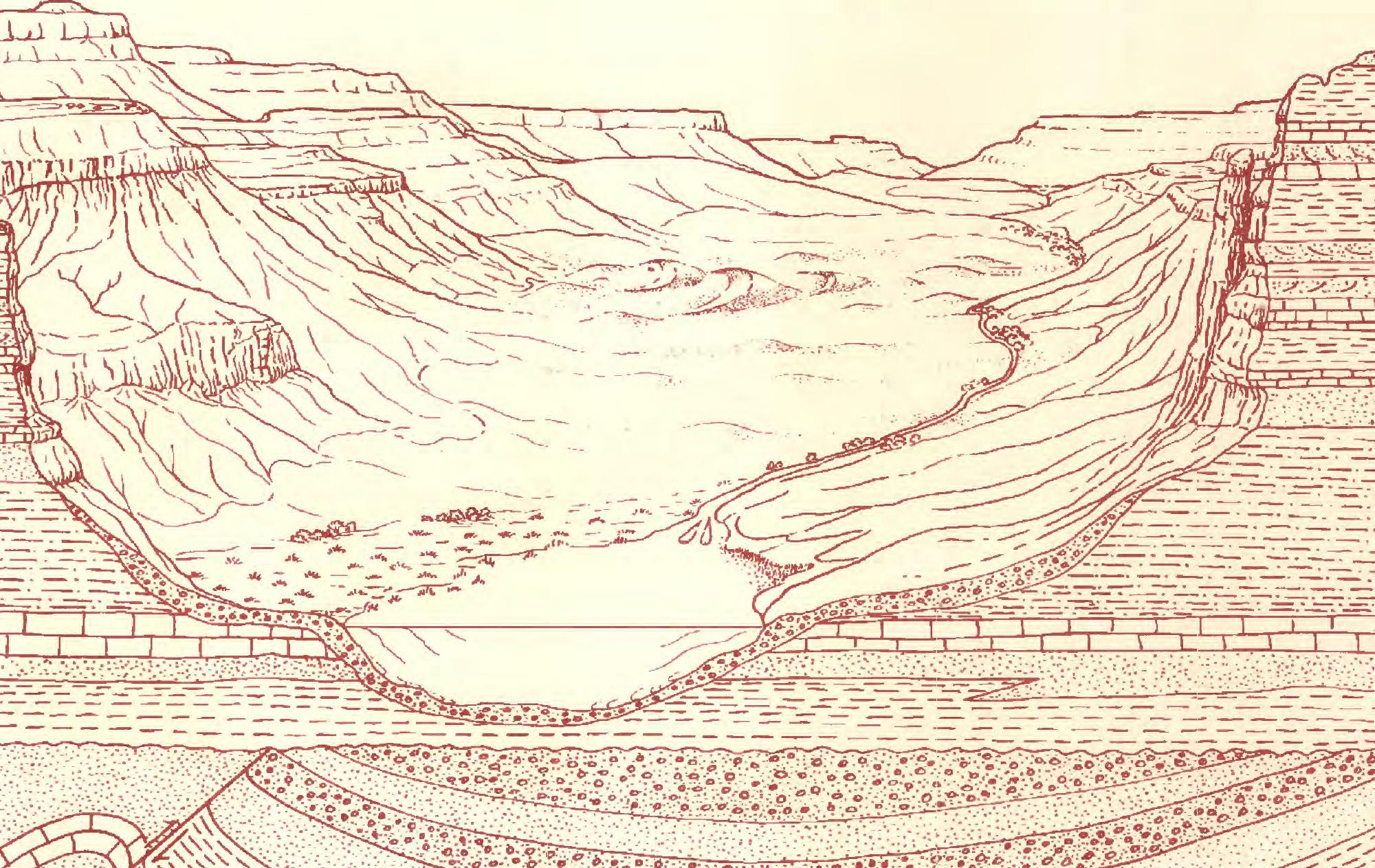


Chapter G

\section{Complete Bouguer and Isostatic Residual Gravity Maps of the Anadarko Basin, Wichita Mountains, and Surrounding Areas, Oklahoma, Kansas, Texas, and Colorado}

By S.L. ROBBINS and G.R. KELLER, JR.

A multidisciplinary approach to research studies of sedimentary rocks and their constituents and the evolution of sedimentary basins, both ancient and modern 


\title{
U.S. DEPARTMENT OF THE INTERIOR
}

MANUEL LUJAN, JR., Secretary

\author{
U.S. GEOLOGICAL SURVEY
}

Dallas L. Peck, Director

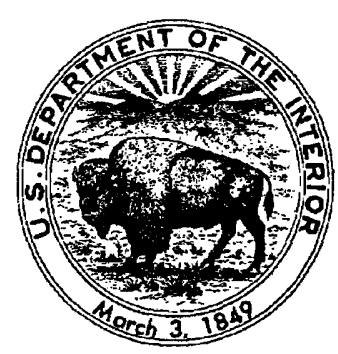

Any use of trade, product, or firm names in this publication is for descriptive purposes only and does not imply endorsement by the U.S. Government

For sale by

Book and Open-File Report Sales

U.S. Geological Survey

Box 25425

Denver, CO 80225

\section{Library of Congress Cataloging-in-Publication Data}

Robbins. S. L.

Complete Bouguer and isostatic residual gravity maps of the Anadarko Basin, Wichita Mountains, and surrounding areas, Oklahoma, Kansas, Texas, and

Colorado / by S.L. Robbins and G.R. Keller, Jr.

p. $\quad \mathrm{cm}$. - (Evolution of sedimentary basins-Anadarko Basin; ch.

G) (U.S. Geological Survey bulletin ; 1866-G)

Includes bibliographical references.

Supt. of Docs. no.: | 19.3:1866-G

1. Gravity anomalies-Anadarko Basin Region. 2. Gravity

anomalies-Anadarko Basin Region-Maps. I. Keller, G. Randy (George

Randy), 1946- II. Title. III. Series. IV. Series: U.S. Geological Survey

bulletin ; 1866-G.

QE75.B9 no. 1866-G

[QB337.5.U5]

$557.3 \mathrm{~s}-\mathrm{dc} 20$

[526'.7'0976] 


\title{
CONTENTS
}

\author{
Abstract $\quad$ G1 \\ Introduction G1 \\ Geologic setting G3 \\ Data compilations $\quad$ G4 \\ Rock unit densities $\quad$ G4 \\ Significance of anomalies G5 \\ Summary G9 \\ References cited G9 \\ PLATES \\ [Plates are in pocket] \\ 1. Complete Bouguer anomaly gravity map of the Anadarko basin, Wichita \\ Mountains, and surrounding areas, Oklahoma, Kansas, Texas, and Colorado. \\ 2. Isostatic residual anomaly gravity map of the Anadarko basin, Wichita Mountains, \\ and surrounding areas, Oklahoma, Kansas, Texas, and Colorado.
}

FIGURES

1-2. Maps showing:

1. Major geologic features in part of study area

2. Basement rocks in part of study area

G3

3-4. Gravity profiles:

3. Across the Wichita uplift G6

4. In the Anadarko basin G8

TABLE

1. Summary of previously published density data G5 



\title{
Complete Bouguer and Isostatic Residual Gravity Maps of the Anadarko Basin, Wichita Mountains, and Surrounding Areas, Oklahoma, Kansas, Texas, and Colorado
}

\author{
By S.L. Robbins and G.R. Keller, Jr. ${ }^{1}$
}

\begin{abstract}
Complete Bouguer and isostatic residual gravity maps of the Anadarko basin, Wichita Mountains, and surrounding areas in parts of Oklahoma, Kansas, Texas, and Colorado were compiled using gravity data from 11,023 stations. The most prominent features on these maps are gravity highs over the Amarillo-Wichita and Arbuckle uplifts and the Muenster arch. These highs are assumed to be caused by Late ProterozoicCambrian high-density gabbroic and volcanic rocks that are believed to be part of an aulacogen. Other features on the maps include (1) a north-northeast-trending high that may be associated with a southern extension of the Midcontinent gravity high, about one degree of longitude west of the Nemaha uplift, (2) an arcuate gravity high in the southeastern corner of the study area that probably represents the southern margin of the North American continent during the Late Proterozoic, (3) a very large gravity low associated with the Arkoma basin and Ouachita Mountains thrust belt, (4) gravity lows associated with most of the Paleozoic basins in the region, (5) no apparent gravity expression of the Nemaha ridge, and (6) broad gravity highs that are probably caused by dense mafic igneous rocks in the basement. These broad gravity highs and the fact that the gravity low over the Anadarko basin is higher over the deepest part of the basin than in other parts of the basin indicate that many, if not most, of the anomalies are caused by differences in basement rock types and densities.
\end{abstract}

\section{INTRODUCTION}

This report includes two gravity maps of the Anadarko basin, Wichita Mountains, and surrounding areas

Manuscript approved for publication April 23, 1990.

${ }^{1}$ University of Texas at El Paso, Department of Geological Sciences, El Paso, Texas 79968. (plates 1 and 2) in parts of Oklahoma, Colorado, Kansas, and Texas. Plate 1 is a black-line complete Bouguer anomaly gravity map showing station locations, cultural features, and basement structures. Plate 2 is an isostatic residual anomaly gravity map in color of the same area. The map area (fig. 1) is between lat $33^{\circ}$ and $39^{\circ} 30^{\prime} \mathrm{N}$., and long $95^{\circ}$ and $103^{\circ} \mathrm{W}$.

These gravity maps were compiled as part of the Anadarko Basin Project, an element of the U.S. Geological Survey Evolution of Sedimentary Basins Program. The map area is much larger than the basin area in order that regional gravity signatures which may have been affected by the evolution of this basin can be evaluated. A map (fig. 2) showing basement rock types (as determined from both surface outcrops and borehole penetrations) is presented for comparison with the gravity signatures.

The Anadarko basin is one of the major sedimentary basins of North America in terms of both its lateral extent and depth. It is part of a complex set of structural features that formed in the southern Midcontinent area as a result of early Paleozoic rifting and subsequent late Paleozoic plate convergence. This set of features extends from northeastern Texas into Colorado (Larson and others, 1985).

Although the Anadarko basin has been studied intensively owing to the long history of oil and gas exploration in the area, relatively few geophysical studies have been published. Deep seismic studies are limited to a long refraction line across Oklahoma interpreted by Mitchell and Landisman (1970), reflection profiles in the southwestern part of the basin recorded by the Consortium for Continental Reflection Profiling (COCORP) (Brewer and others, 1983), and a wide-angle reflection/refraction experiment conducted by the University of Texas at Dallas and the University of Texas at El Paso (Chang and others, 1989; Hamilton, 1989). The long refraction line data are of low resolution because the recording spreads were about 15 $\mathrm{km}$ apart. The COCORP and wide-angle studies focused 


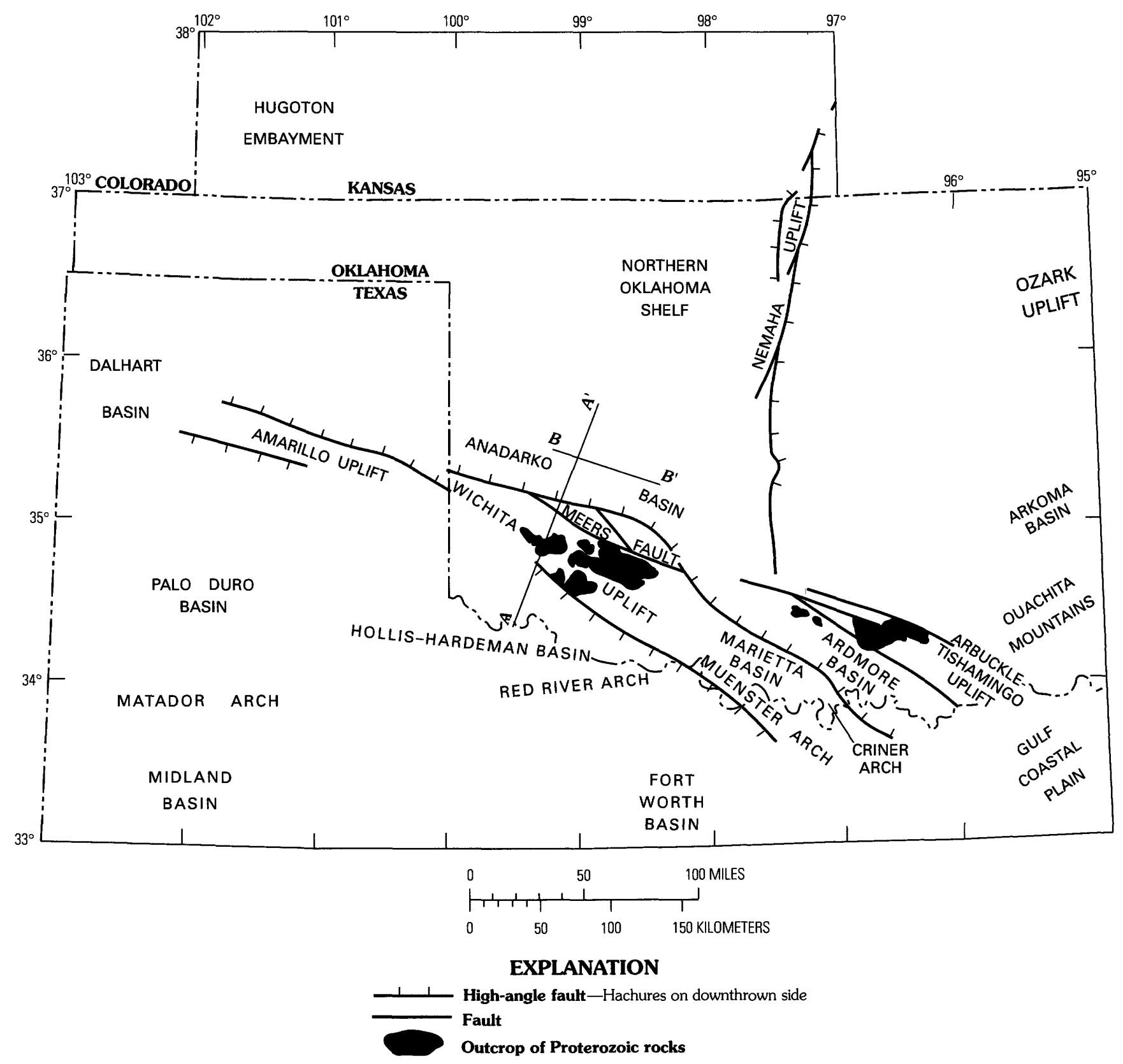

Figure 1. Major geologic features in part of study area, Oklahoma, Texas, and Kansas. Lines of gravity profiles $A-A^{\prime}$ (fig. 3 ) and $B-B^{\prime}$ (fig. 4) are also shown.

primarily on the Wichita uplift but provide valuable constraints on deep structure.

The numerous gravity studies in the Anadarko basin area establish the existence of many large (>50 $\mathrm{mGal}$ ) anomalies, which generally correlate with features known from drilling and geologic mapping. Early studies include a gravity map of the area (Logue, 1954), a gravity map of Oklahoma (Lyons, 1964), and analysis of the gravity field of the western part of the study area (southern High Plains) (Shurbet, 1964). More recent work includes gravity studies of the Amarillo uplift (Danbom, 1969; Goldstein, 1982a, b), modeling of the large anomaly associated with the Wichita uplift (Pruatt, 1975; Papesh, 1983; Coffman and others, 1986), regional analysis of anomalies associated with the Ouachita orogenic belt (Kruger and Keller, 1986), studies of various local features in the area (Scott, 1968; Santiago, 1979; Barrett, 1980; Burchet and others, 1985; Hayden, 1985; Thomson, 1986; Ferris, 1987), and modeling the evolution of the Anadarko basin (Garner and Turcotte, 1984). A brief introduction to some of the ideas in this report and an analysis of two detailed gravity lines across the Meers fault are given in Robbins and others (1989). 


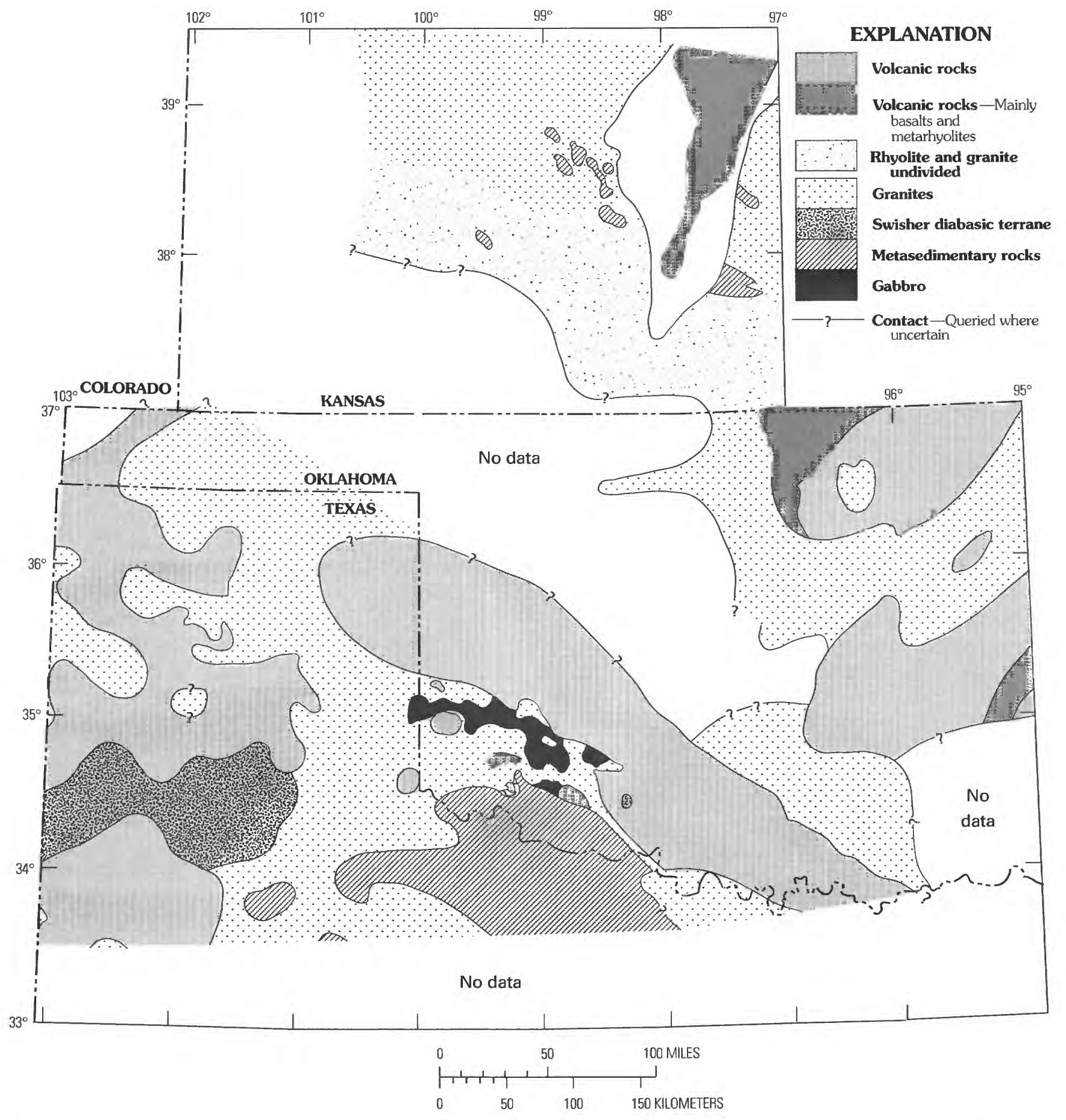

Figure 2. Basement rocks in part of study area, Oklahoma, Texas, and Kansas. Modified from Rasco and Hyme (1987).

Many of these studies provide valuable data, but these data have not been compiled into a coherent data base. One task in our study was to add these data to data bases maintained by the Defense Mapping Agency and the University of Texas at El Paso and to obtain new data in key areas with sparse coverage. Our ultimate goal is to conduct a regional analysis of gravity anomalies in the area of the Anadarko basin.

\section{GEOLOGIC SETTING}

The Anadarko basin is the deepest Phanerozoic sedimentary basin in North America. Locally it contains more than $12 \mathrm{~km}$ of Cambrian through Permian sedimentary rocks (Ham and Wilson, 1967), mostly deposited in shallow-water environments. The basin is deepest along its southern margin. 
The Wichita uplift is just south of and adjacent to the Anadarko basin. The boundary between the basin and uplift is complexly faulted and abrupt (Harlton, 1963; Perry, 1989). The uplift is primarily composed of Cambrian igneous rocks of diverse compositions (Gilbert, 1983) and is part of a major structural feature that extends from northeastern Texas, where it is known as the Muenster arch, through southwestern Oklahoma to northwestern Texas, where it is known as the Amarillo uplift (fig. 1).

Sedimentary rocks north of the Anadarko basin, in northern Oklahoma and into southern Kansas, are predominantly Paleozoic in age and probably represent facies equivalents of the sediments deposited in the basin.

Structural relations in southeastern Oklahoma are more complex (fig. 1). The Ardmore basin is a narrow, southeast extension of the Anadarko basin. The ArbuckleTishamingo uplift bounds the Ardmore basin on the north, and granites in the eastern part of the uplift are the oldest exposed rocks in the area, dated as approximately $1.4 \mathrm{Ga}$ (Bickford and Lewis, 1979). Cambrian igneous rocks in the western part of the uplift are similar to those in the Wichita uplift, and Paleozoic sedimentary rocks exposed in the uplift are similar to those in the Anadarko basin. The Criner arch, Marietta basin, and Muenster arch bound the Ardmore basin on the south.

Strata in the Ouachita Mountains area consist of a thick succession of folded and faulted Paleozoic sedimentary rocks, similar in age to rocks in the Anadarko and Ardmore basins. They are dominated, however, by fine-grained clastic rocks and cherts and include almost no carbonate rocks, and they represent a deep-water environment. Late Paleozoic deformation is in the form of a major thin-skin thrusting to the north and west (Hendricks and others, 1947).

Relatively shallow-dipping Jurassic and younger marine sedimentary rocks of the Gulf Coast Plain crop out in the southeastern corner of the map area. They include salt deposits, carbonate rocks, and fine-grained clastic rocks.

The tectonic history of the region has been comprehensively discussed by Ham and others (1964) and was interpreted within a plate tectonic framework by Hoffman and others (1974), Gilbert (1983), and Keller and others (1983). Shatski (1946) first interpreted the southern Oklahoma area as a classic example of an aulacogen, and Burke and Dewey (1973) viewed the area as a failed arm of a triple-junction rift complex that was later reactivated. Although many points about the tectonic development of this region are debated, it is generally agreed that Proterozoic-Cambrian rifting was followed by gradual subsidence (Perry, 1989). The resulting basins were then deformed in the late Paleozoic during plate collision (possibly with Gondwana or an intervening microplate) (Perry, 1989) that produced the Ouachita orogeny. Late Paleozoic features in Oklahoma are part of an extensive complex of structural features that includes the ancestral Rocky Mountains (for example, Kluth and Coney, 1981; Budnick, 1986; Kluth, 1986).

\section{DATA COMPILATIONS}

Gravity data from 11,023 gravity stations were used in the compilations of these maps. Station locations are shown on plate 1. Data for 5,821 stations are from the University of Texas at El Paso, for 3,607 stations from the Defense Mapping Agency, for 652 stations from Barrett (1980), Santiago (1979), Hayden (1985) and Thomson (1986), and for 87 stations from H.C. Gilbert and E. Robinson (1988, written commun.). In addition, the first author used a LaCoste and Romberg gravity meter to collect regional gravity data at 365 locations in south-central Oklahoma and at 156 locations in southern Kansas and closely spaced gravity data along three profiles that cross the Meers fault in Oklahoma (Robbins and others, 1990). Principal facts for the data collected by the first author and by Barrett, Hayden, Santiago, Thomson, and Gilbert and Robinson are tabulated in Robbins and others (1991).

All gravity values are based on the IGSN-1971 datum (Morelli, 1974), and the data were reduced using the GRS-1967 formulas (International Association of Geodesy, 1971) and an assumed average crustal density of 2.67 $\mathrm{g} / \mathrm{cm}^{3}$. The terrain effect to a distance of $167 \mathrm{~km}$ from each station was removed using a computer program based on Plouff (1977). The terrain effect for the stations established by the first author was removed by manually making corrections to a distance of $0.59 \mathrm{~km}$ and using the computer program from 0.59 to $167 \mathrm{~km}$. Isostatic corrections were made using a computer program by Simpson and others (1983) that is based on an Airy-Heiskanen compensation model. The parameters used for this model are (1) density of the topographic load, $2.67 \mathrm{~g} / \mathrm{cm}^{3}$; (2) depth of the root below sea level, $30 \mathrm{~km}$; and (3) density contrast at depth, $+0.4 \mathrm{~g} / \mathrm{cm}^{3}$. The black-line complete Bouguer gravity map (plate 1) was contoured using the program "Interactive Surface Modelling" by Dynamic Graphics, Inc., and the colored isostatic residual gravity map (plate 2) was generated by gridding the data using a computer program by Webring (1981) and plotting the gridded data using the program COLOR by Godson (1980). A 1.6-km grid interval was used in contouring both maps. Plate 1 is contoured at a $21 / 2-\mathrm{mGal}$ interval and plate 2 at a 5 -mGal interval. Both maps are at a scale of $1: 1,000,000$.

\section{ROCK UNIT DENSITIES}

Density data are necessary in any quantitative interpretation of gravity data; however, data from very few direct density measurements on the rock units in this area 
have been published. Table 1 summarizes currently available density data, most of which are for igneous and metamorphic rocks (Chase and others, 1956; Denison, 1966).

Most published data for sedimentary rocks are for Pennsylvanian and Permian rocks (Athy, 1930; Clark, 1966). Density values for other sedimentary rocks in the various gravity investigations listed earlier in the introduction are based on assumptions for typical rock types (Dobrin, 1960). The density tables of Goldstein (1982a, b) are based both on analysis of local density logs and on values for typical rock types, and density values are given in terms of rock types, not stratigraphic units. Scott (1968), in discussing the significance of the use of gravity in the Anadarko basin, stated that "Information derived from samples, cores, and density logs indicate that the major contrasts exist at the top of the Mississippian carbonate, Hunton, Viola, and Arbuckle formations."

\section{SIGNIFICANCE OF ANOMALIES}

The complete Bouguer anomaly gravity (CBA) map (plate 1) depicts lateral variations in the density of the lithosphere. In order to produce a gravity map that is more representative of lateral density variations in only the upper crust (that is, the removal of the regional field), an estimate of the regional effect due to the correlation of the Bouguer anomalies and topography was removed by assuming a simple isostatic compensation density model (Simpson and others, 1983), thus creating the isostatic residual anomaly gravity (IRA) map (plate 2). In comparing the two maps, the most obvious difference is the removal of the west to east increase in values from the CBA map. In addition, the IRA map shows the large gravity low over the Ouachita Mountains to be the largest negative anomaly. In the following discussion, the focus is on anomalies as seen on the IRA map.

The most prominent features on the IRA map are the gravity highs $(50-80 \mathrm{mGal})$ over the Amarillo-Wichita and Arbuckle-Tishamingo uplifts and the Muenster arch. These highs have been assumed to be caused by ProterozoicCambrian rift-related, high-density gabbroic and volcanic rocks similar to those exposed at the surface. The large magnitude of the highs and the high seismic velocities at depth (Chang and others, 1989) indicate that a large volume of mafic and ultramafic rocks is in the crust beneath the Wichita uplift. Models by Pruatt (1975), Papesh (1983), and Coffman and others, (1986) show that this mass requires a density of about $3.0 \mathrm{~g} / \mathrm{cm}^{3}$ in the upper crust. Thinning of the crust could also account for part of these highs; however, seismic data (Brewer and others, 1983; Chang and others, 1989) do not indicate crustal thinning. These highs are similar in magnitude to highs over the southern end of the Midcontinent gravity high (northern Kansas, northeastern corner of the map area of plates 1 and 2). 

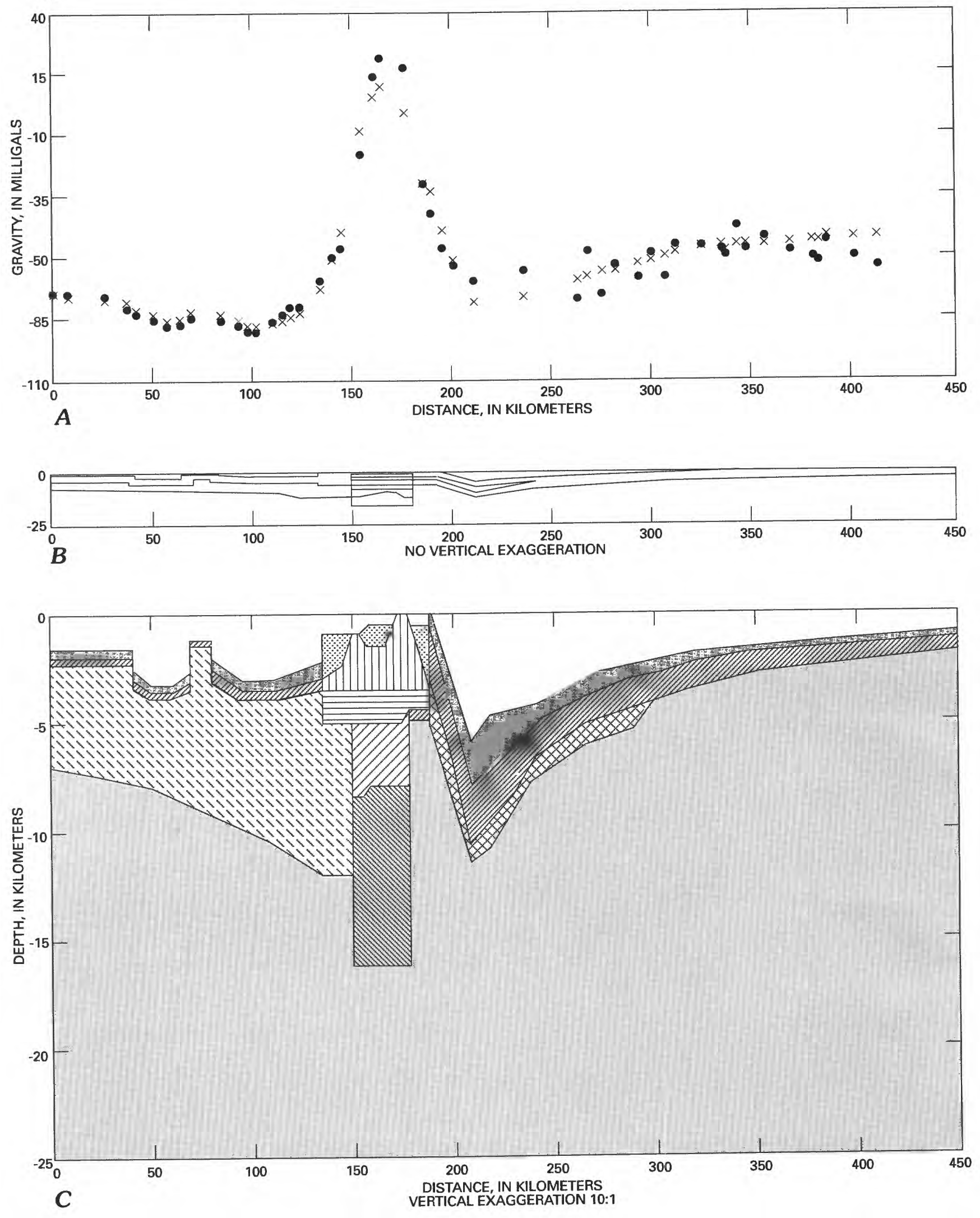


\section{EXPLANATION \\ - Observed \\ $\times$ Predicted}

\section{EXPLANATION}

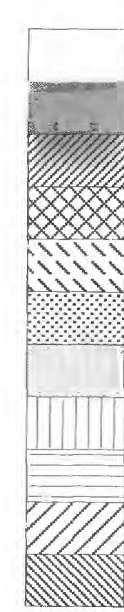

Lithology
Pennsylvanian and Permian rocks
Devonian and Mississippian rocks
Upper Cambrian to Devonian rocks
Late Proterozoic and Cambrian igneous rocks
Tillman Metasedimentary Group
Granite
Crust
Gabbro body G1
Gabbro body G2
Gabbro body G3
Gabbro body G4

Density $\left(\mathrm{g} / \mathrm{cm}^{3}\right)$

2.5

2.63

2.75

2.64

2.6

2.6

2.7

2.64

2.735

2.85

2.96

Figure 3. (above and facing page). Gravity profile $A-A^{\prime}$ across the Wichita uplift. Line of profile is shown on figure 1. Modified from Hamilton (1989).

Hamilton (1989) has combined gravity data and wide-angle reflection/refraction seismic data to construct a detailed model (fig. 3) in which he interpreted the high-density material as gabbro having a density of $2.96 \mathrm{~g} / \mathrm{cm}^{3}$ to a depth of about $16 \mathrm{~km}$.

The gravity low of $40 \mathrm{mGal}$ or more over the Anadarko basin is centered well west of the deepest part of the basin. Although an anomaly shift of this type could be caused by significant lateral facies changes and density differences within rocks of the sedimentary basin, no published evidence supports this idea. Therefore, we suggest that many of the gravity anomalies on this map are caused by differences in basement rock types and densities. Also, just east of long $99^{\circ} \mathrm{W}$., north of lat $35^{\circ} \mathrm{N}$. and just north of the Wichita uplift gravity high, a $20-30-\mathrm{mGal}$ gravity high trends north-northeast. This high is approximately over the deepest part of the Anadarko basin about one full degree of longitude west of the Nemaha uplift, and it is probably caused by density increases within the basement rocks. It is on line with the southern extent of the Midcontinent gravity high and may be caused by deeply buried, high-density volcanic rocks of Keweenawan age (Halls, 1978). Figure 4 shows a simple two-dimensional model of the gravity effect of a high-density body, such as a basalt or gabbro, in the basement beneath the Anadarko basin fill at a depth of $9 \mathrm{~km}$. The match between the observed and calculated gravity data is very good for a body that is $10 \mathrm{~km}$ thick and $13 \mathrm{~km}$ wide and has a density contrast of $+0.25 \mathrm{~g} / \mathrm{cm}^{3}$ with the surrounding rocks. Outcrop data demonstrate that mafic flow rocks are associated with the Midcontinent gravity high in the Lake Superior region (Halls, 1978). Nixon and Ahern (1988) have also proposed an extension of the Midcontinent gravity high into northcentral Oklahoma, and magnetic data (Jones and Lyons, 1964) support this extension.

The bounding on both sides of the Amarillo-Wichita uplift gravity high by steep gradients suggests a fairly narrow zone of faulting with significant vertical (subsurface) relief for the uplifted block. On the north side, there is about $12 \mathrm{~km}$ of structural relief over a horizontal distance of only about $25 \mathrm{~km}$ from the maximum sedimentary rock thickness in the Anadarko basin to outcrops of Late Proterozoic to Cambrian igneous rocks (Ham and others, 1964). Interpretations of the nature of faulting along this boundary are controversial and involve differing views on the relative importance of shortening (for example, Ham and others, 1964; Denison, 1982) and lateral movements (for example, Budnick, 1986) during the late Paleozoic development of the area. Seismic data recently collected by COCORP (Brewer and others, 1983) and the Universities of Texas at Dallas and El Paso (Chang and others, 1989) demonstrate, however, that deep-seated southwest-dipping thrust faults are along the southern boundary of the basin. Interpretations stressing strike-slip movements must account for these faults. In the area near the Meers fault (lat $34^{\circ} 30^{\prime}-35^{\circ} \mathrm{N}$., long $98^{\circ} 30^{\prime}-99^{\circ} \mathrm{W}$.), the Wichita gravity high is widest, and the gravity gradient on the north side of the uplift is most gentle. In addition, the gradient changes trend from northeast east of the Meers 

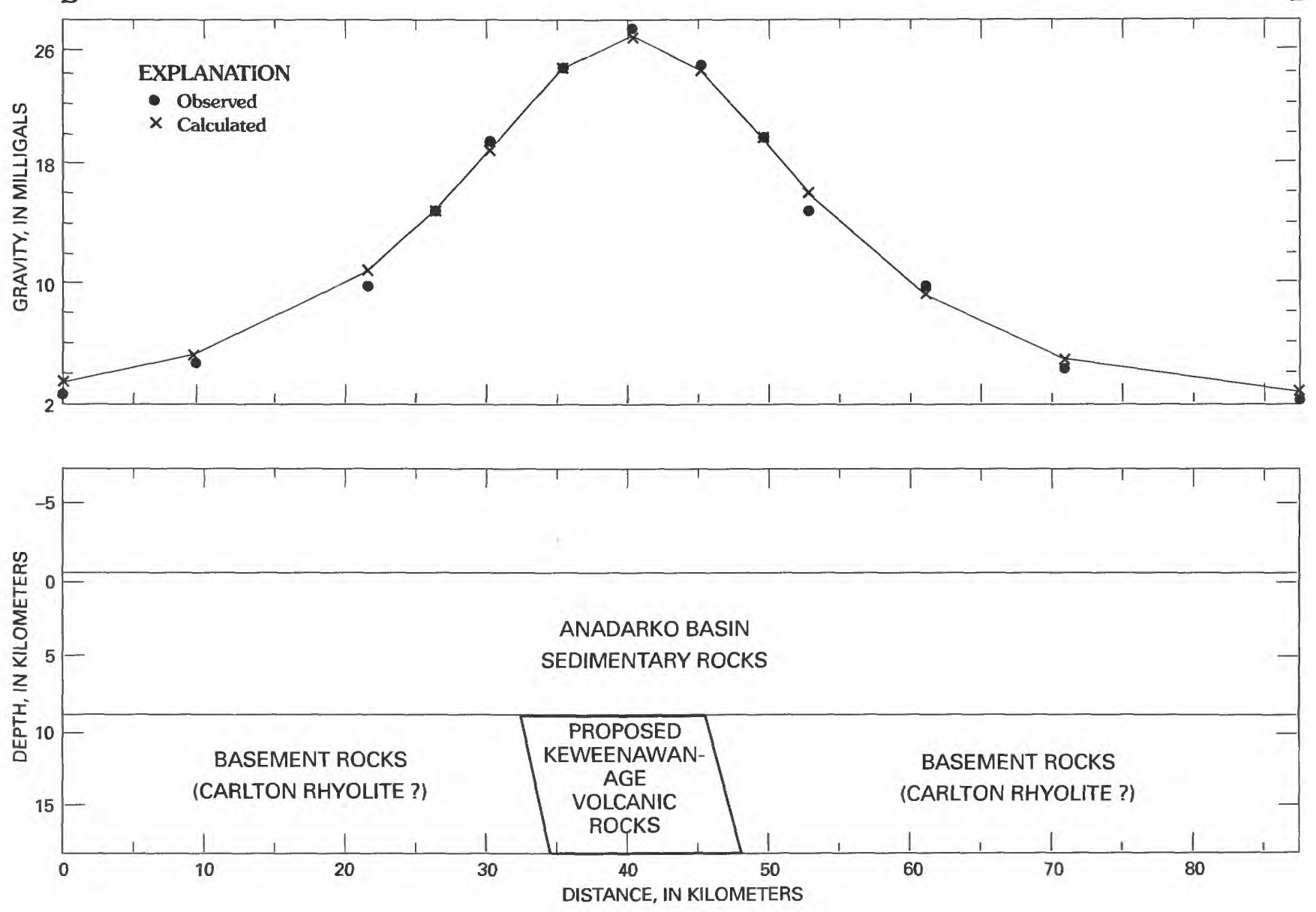

Figure 4. Gravity profile $B-B^{\prime}$ in the Anadarko basin. Line of profile is shown on figure 1.

fault to more northerly west of the fault. Just north of this change, the north-northeast-trending $20-30-\mathrm{mGal}$ gravity high begins. The geology of this part of the gradient is more complex and includes both thrust and strike-slip faults that strike in several different directions and surface outcrops of highly deformed lower Paleozoic rocks.

Just south of the Arbuckle uplift gravity high a gravity low (15-20 mGal) over the Ardmore basin indicates that this basin is a narrow structural feature between two major uplifts.

Possible causes for the arcuate gravity high (20-30 $\mathrm{mGal}$ ) in the southeastern corner of the map include crustal thinning, metamorphic effects (densification), basement uplift, mafic intrusive rocks, and accreted material (Kruger and Keller, 1986). Kruger and Keller stated that "these interpretations may be valid locally, but a single interpretation probably is not valid along the entire length of this anomaly (Arkansas to Mexico)." They and Keller and others (1989) suggested that this anomaly represents the southern margin of the North American continent during the
Late Proterozoic. The decreasing gravity gradient southeast of this high is over the northwestern extent of Gulf coastal plain sedimentary rocks. Cretaceous rocks at the surface extend northwest over the possible ancestral continental margin.

The east-trending gravity highs across Texas in the lower part of the map generally follow the trend of the Matador and Red River arches. However, individual gravity highs (as high as $50 \mathrm{mGal}$ ) probably are associated with intrusive centers (Shurbet and others, 1976), not basement relief.

The very large gravity low $(86 \mathrm{mGal})$ in southeastern Oklahoma over the Ouachita Mountains and Arkoma basin extends into western Arkansas and is one of the largest gravity lows on the North American continent. Kruger and Keller (1986) showed that this anomaly can best be interpreted as the signature of the Arkoma basin; the basin is deepest (about $15 \mathrm{~km}$ ) beneath the Ouachita Mountains, which have been thrust northward over the southern half of the original basin. 
North of this large low, along the east edge of the map between lat $36^{\circ}$ and $37^{\circ} \mathrm{N}$., a small high $(6-8 \mathrm{mGal})$ is over the western part of the Ozark uplift.

Several broad gravity highs (10-20+ mGal) over the northern Oklahoma shelf or platform area are probably caused by dense mafic igneous rocks that were intruded into the granitic basement (Santiago, 1979; Barrett, 1980). The Nemaha ridge between lat $35^{\circ}$ and $37^{\circ} \mathrm{N}$. is at about long $97^{\circ} 30^{\prime} \mathrm{W}$. The ridge appears to cut across a gravity high and a low, proceeding from south to north. The lack of apparent gravity expression of the ridge at this regional scale supports the argument that most of the anomalies shown on the IRA map are caused by differences in basement compositions.

The gravity field over the Hugoton embayment in southwestem Kansas includes several broad highs and lows $( \pm 15-25 \mathrm{mGal})$ that also are probably due to variations in basement rock types because no evidence exists for significant facies changes in the sedimentary rocks within the embayment.

\section{SUMMARY}

Results of analysis of the isostatic residual anomaly gravity map (plate 2) are in agreement with the prevailing interpretation of the tectonic history of the region. Large gravity highs associated with the Amarillo-Wichita uplift and Muenster arch indicate high-density gabbroic and volcanic rocks at depth, consistent with the aulacogen or failed rift concept. Proterozoic-Cambrian rifting was followed by a long period of gradual subsidence (about 200-250 m.y.) that resulted in an elongate sedimentary basin (southern Oklahoma trough of Perry, 1989). Starting in the Late Mississippian and extending into the Permian, a major period of tectonic activity may have been caused by the collision between the North American plate and Gondwana or an intervening microplate (Perry, 1989). This tectonic activity caused the rift complex to be thrust upward, thus dividing the older southern Oklahoma trough and creating the Amarillo-Wichita-Muenster uplift. Subsidence and sedimentation continued north of this area of structural inversion until some time in the Permian. Large gravity lows are associated with each of the resulting successor basins. The largest gravity low on the map is over a part of the Arkoma basin that lies beneath the thrust plate of the Ouachita Mountains, which was emplaced during this same tectonic activity. The arcuate gravity high in the southeastern corner of the map area probably represents the early Paleozoic continental margin of North America.

Within the Anadarko basin and northward onto the Oklahoma platform and extending into southern Kansas and into the Hugoton embayment, a number of broad gravity highs are probably associated with differences in basement rock types and densities and (or) dense mafic igneous rocks in the basement. One high that extends northward from the northern edge of the Wichita uplift and trends northnortheast through the deepest part of the Anadarko basin into southern Kansas may represent the southern extension of the Midcontinent gravity high.

\section{REFERENCES CITED}

Athy, L.F., 1930, Density, porosity, and compaction of sedimentary rocks: American Association of Petroleum Geologists Bulletin v. 14, no. 1, p. 1-24.

Barrett, Christopher, 1980, A gravity and magnetic study of the Kingfisher anomaly, north-central Oklahoma: Norman, University of Oklahoma, M.S. thesis, 45 p.

Bickford, M.E., and Lewis, R.D., 1979, U-Pb geochronology of exposed basement rocks in Oklahoma: Geological Society of America Bulletin, v. 90, p. 540-544.

Brewer, J.A., Good, R., Oliver, J.E., Brown, L.D., and Kaufman, S., 1983, COCORP profiling across the southern Oklahoma aulacogen; overthrusting of the Wichita Mountains and compression within the Anadarko basin: Geology, v. 11, no. 2, p. 109-114.

Budnik, R.T., 1986, Left-lateral intraplate deformation along the Ancestral Rocky Mountains; implications for late Paleozoic plate motions: Tectonophysics, v. 132, p. 195-214.

Burchett, R.R., Luza, K.V., Van Eck, O.J., and Wilson, F.W., 1985, Seismicity and tectonic relationships of the Nemaha uplift and Midcontinent geophysical anomaly (final project summary): Oklahoma Geological Survey Special Publication 85-2, 33 p.

Burke, K., and Dewey, J.F., 1973, Plume-generated triple junctions; key indicators in applying plate tectonics to old rocks: Journal of Geology, v. 81, p. 406-433.

Chang, W.-F., McMechan, G.A., and Keller, G.R., 1989, Wavefield processing of data from a large-aperture seismic experiment in southwestern Oklahoma: Journal of Geophysical Research, v. 94, no. B2, p. 1803-1816.

Chase, G.W., Frederickson, E.A., and Ham, W.E., 1956, Résumé of the geology of the Wichita Mountains, Oklahoma, in Petroleum geology of southern Oklahoma: American Association of Petroleum Geologists and Ardmore Geological Society, Symposium, v. 1, p. 36-55.

Clark, S.P., Jr., ed., 1966, Handbook of physical constants: Geological Society of America Memoir 97, $587 \mathrm{p}$.

Coffman, J.D., Gilbert, M.C., and McConnell, D.A., 1986, An interpretation of the crustal structure of the southern Oklahoma aulacogen satisfying gravity data: Oklahoma Geological Survey Guidebook 23. p. 1-10.

Danbom, S.H., 1969, A gravity and magnetic investigation of the Amarillo uplift: Lubbock, Texas Technological College, M.S. thesis, $60 \mathrm{p}$.

Denison, R.E., 1966, Basement rocks in adjoining parts of Oklahoma, Kansas, Missouri, and Arkansas: Austin, University of Texas, Ph.D. thesis, $292 \mathrm{p}$.

Dobrin, M.B., 1960, Introduction to geophysical prospecting: New York, McGraw-Hill, 446 p.

Ferris, Craig, 1987, Gravity anomaly resolution at the Garber field: Geophysics, v. 52, no. 11, p. 1570-1579.

Garner, D.L., and Turcotte, D.L., 1984, The thermal and mechanical evolution of the Anadarko basin: Tectonophysics, v. 107 , p. 1-24. 
Gilbert, M.C., 1983, The Meers fault of southwestern Oklahoma; evidence for possible strong Quaternary seismicity in the Midcontinent [abs.]: Transactions of the American Geophysical Union, v. 64, p. 313.

Godson, R.H., 1980, Program COLOR: U.S. Geological Survey unpublished report, $13 \mathrm{p}$.

Goldstein, A.G., 1982a, Quantitative analysis of regional Bouguer gravity data, in Geology and geohydrology of the Palo Duro basin, Texas panhandle: Texas Bureau of Economic Geology Geological Circular 82-7, p. 11-17.

1982b, Structural geology, in Dutton, S.P., Goldstein, A.G., and Ruppel, S.C., Petroleum potential of the Palo Duro basin, Texas panhandle: Texas Bureau of Economic Geology Report of Investigations 123, p. 53-59.

Halls, H.C., 1978, The late Precambrian central North American rift system-A survey of recent geological and geophysical investigations, in Ramberg, I.B., and Neumann, E.R., eds., Tectonics and geophysics of continental rifts: Boston, D. Reidel, p. 111-123.

Ham, W.E., Denison, R.E., and Merritt, C.A., 1964, Basement rocks and structural evolution of southern Oklahoma: Oklahoma Geological Survey Bulletin 95, 302 p.

Ham, W.E., and Wilson, J.L., 1967, Paleozoic epeirogeny and orogeny in the central United States: American Journal of Science, v. 265 , p. $332-407$.

Hamilton, L.S., 1989, Structure of the Wichita uplift, southern Oklahoma, from a wide-angle seismic experiment: E1 Paso, University of Texas, M.S. thesis, $93 \mathrm{p}$.

Harlton, B.J., 1963, Frontal Wichita fault system of southwestern Oklahoma: Bulletin of the American Association of Petroleum Geologists, v. 47, no. 8, p. 1552-1580.

Hayden, J.M., 1985, A gravity and magnetic investigation of a microseismically active area in central Oklahoma: Norman, University of Oklahoma, M.S. thesis, 175 p.

Hendricks, T.A., Gardner, L.S., Knechtel, M.M., and Averitt, P., 1947, Geology of the western part of the Ouachita Mountains of Oklahoma: U.S. Geological Survey Oil and Gas Investigations Preliminary Map 66, scale 1:42,240.

Hoffman, P., Dewey, J.F., and Burke, K., 1974, Aulacogens and their genetic relation to geosynclines, with a Proterozoic example from Great Slave lake, in Dott, R.H., Jr., and Shaver, R.H., eds., Modern and ancient geosynclinal sedimentation: Society of Economic Paleontologists and Mineralogists Special Publication 19, p. 38-55.

International Association of Geodesy, 1971, Geodetic reference system 1967: International Association of Geodesy Special Publication 3, $116 \mathrm{p}$.

Jones, V.L., and Lyons, P.L., 1964, Vertical-intensity magnetic map of Oklahoma: Oklahoma Geological Survey Map GM-6, scale 1:750,000.

Keller, G.R., Braile, L.W., McMechan, G.A., Thomas, W.A., Harder, S.H., Chang, W.F., and Jardine, W.G., 1989, Paleozoic continent-ocean transition in the Ouachita Mountains imaged from PASSCAL wide-angle seismic reflection-refraction data: Geology, v. 17, no. 2, p. 119-122.

Keller, G.R., Jr., Lidiak, E.G., Hinze, W.J., and Braile, L.W., 1983, The role of rifting in the tectonic development of the Midcontinent, U.S.A.: Tectonophysics, v. 94, p. 391-412.
Kluth, C.F., 1986, Plate tectonics of the ancestral Rocky Mountains, in Peterson, J.A., ed., Paleotectonics and sedimentation in the Rocky Mountain region, United States: American Association of Petroleum Geologist Memoir 41, p. 353-369.

Kluth, C.F., and Coney, P.J., 1981, Plate tectonics of the ancestral Rocky Mountains: Geology, v. 9, no. 1, p. 10-15.

Kruger, J.M., and Keller, G.R., 1986, Interpretation of crustal structural from regional gravity anomalies, Ouachita Mountains area and adjacent Gulf coastal plain: American Association of Petroleum Geologists Bulletin, v. 70, no. 6, p. 667-689.

Larson, E.E., Patterson, P.E., Curtis, G., Drake, R., and Mutschler, F.E., 1985, Petrologic, paleomagnetic, and structural evidence of a Paleozoic rift system in Oklahoma, New Mexico, Colorado, and Utah: Geological Society of American Bulletin, v. 96, p. 1364-1372.

Logue, L.L., 1954, Gravity anomalies of Texas, Oklahoma, and the United States: The Oil and Gas Journal, April 19, p. 132-135.

Lyons, P.L., 1964, Bouguer gravity-anomaly map of Oklahoma: Oklahoma Geological Survey Map GM-7, scale 1:750,000.

Mitchell, B.J., and Landisman, M., 1970, Interpretation of a crustal section across Oklahoma: Geological Society of America Bulletin, v. 81, no. 9, p. 2647-2656.

Morelli, C., ed., 1974, The international gravity standardization net 1971: International Association of Geodesy Special Publication 4, $194 \mathrm{p}$.

Nixon, G.A., and Ahern, J.L., 1988, Southern extension of the Midcontinent geophysical anomaly; evidence for $\mathrm{Ke}$ weenawan rifting in north-central Oklahoma: Geological Society of America Abstracts with Programs, v. 20, no. 7, p. A234.

Papesh, Henry, 1983, A regional geophysical study of the southern Oklahoma aulacogen: El Paso, University of Texas, M.S. thesis, $68 \mathrm{p}$.

Perry, W.J., Jr., 1989, Tectonic evolution of the Anadarko basin: U.S. Geological Survey Bulletin 1866-A, 19 p.

Plouff, Donald, 1977, Preliminary documentation for a FORTRAN program to compute gravity terrain corrections based on topography digitized on a geographic grid: U.S. Geological Survey Open-File Report 77-535, 45 p.

Pruatt, M.A., 1975, The southern Oklahoma aulacogen; a geophysical and geological investigation: Norman, University of Oklahoma, M.S. thesis, 59 p.

Rascoe, Bailey, and Hyne, N.J., 1987, Petroleum geology of the Midcontinent: Tulsa Geological Society Special Publication 3, $162 \mathrm{p}$.

Robbins, S.L., Jones-Cecil, Meridee, and Keller, G.R., Jr., 1989, Regional gravity of the Anadarko basin and a more detailed look at the Wichita fault zone, in Johnson, K.S., ed., Anadarko basin symposium, 1988: Oklahoma Geological Survey Circular 90, p. 225-227.

Robbins, S.L., Williamson, Courteney, and Jones-Cecil, Meridee, 1991, Principal facts for 1747 gravity stations in southern Kansas and central Oklahoma: U.S. Geological Survey Open-File Report 91-335, 80 p.

Santiago, D.J., 1979, A gravity and magnetic study of the Medford anomaly, north-central Oklahoma: Norman, University of Oklahoma, M.S. thesis, 105 p. 
Scott, R.L., 1968, The exploratory significance of gravity in the Anadarko basin: Shale Shaker, v. 18 , no. 7, p. 132-150.

Shatski, N.S., 1946, The great Donets basin and the Wichita system; comparative tectonics of ancient platforms: Akademiya Nauk SSSR Izvestiya, Seriya Geologicheskaya, v. 6, p. 57-90.

Shurbet, D.H., 1966, Gravity field and isostatic equilibrium of the Llano Estacado of Texas and New Mexico: Geological Society of America Bulletin, v. 77, no. 2, p. 213-222.

Shurbet, D.H., Keller, G.R., and Friess, J.P., 1976, Remanent magnetization from comparison of gravity and magnetic anomalies: Geophysics, v. 41 , no. 1 , p. 56-61.
Simpson, R.W., Jachens, R.C., and Blakely, R.J., 1983, AIRYROOT; a FORTRAN program for calculating the gravitational attraction of an Airy isostatic root out to 166.7 km: U.S. Geological Survey Open-File Report 83-883, $66 \mathrm{p}$.

Thomson, W.A., III, 1986, A geophysical investigation of a possibly Recent fault in southwestern Oklahoma: Norman, University of Oklahoma, M.S. thesis, 113 p.

Webring, Michael, 1981, MINC; a gridding program based on minimum curvature: U.S. Geological Survey Open-File Report 81-1224, 43 p. 
- 